\title{
The Role and Perception of Customer on Buying Behaviour Towards Real Estate Industry
}

\author{
C. P. Senthil Kumar, M. Karthiga Priya
}

\begin{abstract}
This present study aims to explore the various dimensions and role of customer perception and buying behavior towards the growth of real estate industry in Chennai city of Tamil $\mathrm{Nadu}$. The researcher has adopted survey method to gather the primary information from individuals those who shown interest to purchase and invest in real estate industry. The statistical tools such as, percentage analysis, descriptive statistics, mean based ranking, cluster and discriminant analysis has been applied for 148 samples collected in the study area. The result indicates that three dominant dimensions are significantly determine the purchase of real estate such as, Economic consideration factor, Livilihood Consideration factor and growth factor. Further, the result indicates that two types of purchasers are in the realm of real estate industry namely, individual investor and return seekers significantly differentiated with three purchase consideration factors. The real estate industry provides higher earnings to the buyers across the country to have better investment decisions and economic growth. Thus, leads to higher industrial growth, enhancement in socio economic conditions, strengthening the financial system, increase in financial leverages and lending among the individuals through different types of financial institutions in India.
\end{abstract}

Keywords : Real Estate Industry, Investment Decision, Considerations, Economy and Growth.

\section{INTRODUCTION}

The real estate sector consist of commercial and residential houses, business spaces, hotels, industrial buildings and etc for the purpose of purchase, sale and development of land. The real estate business generally comprises of both the construction and building sector. The real estate sector in India is worth of 12 billion US dollars in the year 2018 which accounts five percentage of India's Gross Domestic Product (GDP) and it is expected to increase six percentages in the upcoming years (IBEF Report 2019). Over the decades the real industry has shown tremendous growth of $30 \%$ as compared to last decade. India is currently destination for many multinational companies to start their own business or company or centers and also attracts many foreign investments to make use of available human as well as natural resources. The real estate industry provides higher returns to the investors in Indian context due to easy mode of operations and low cost budget to make their investment decisions (PWC Report 2014). Thus, leads to higher

Revised Manuscript Received on December 05, 2019.

* Correspondence Author

Dr. C. P. Senthil Kumar, Assistant Professor and Research Supervisor, P.G and Research Department of Commerce, Guru Nanak College (Autonomous), Chennai, Tamil Nadu - India

M. Karthiga Priya*, Part-Time Research Scholar [Internal], P.G and Research Department of Commerce, Guru Nanak College (Autonomous), Chennai, Tamil Nadu - India industrial growth, enhancement in socio economic conditions, strengthening the financial system, increase in financial leverages and lending among the individuals in India. A liberalisation policy helps the Government to open the doors for the foreign companies to think about investment in India. This facilitates the country to attract more foreign direct investment and foreign institutional investment to make the Indian real estate sector to reach the greater heights in global business environment.

\section{REVIEW OF LITERATURE}

Levy, D., Murphy, L., \& Lee, C. K. (2008) have discussed the customers purchase decision of buying a house is embedded within a set of economic and social cultural processes towards operationalised within specific local property market. The author made an attention to focused the customers purchase consideration to buying a housing property with different parameter and that are house prices, life-course and demographic influences on the decision to buy, but less attention has been directed to understanding the internal family decision-making process also plays a significant role. The authors have adopted both qualitative and quantitative approach for this study through the semi-structured interview questionnaire and data were collected from the family respondent recent housing property purchasers. The authors have listed the process of purchasing a residential property is an inherently social activity and it negotiating various family needs. In addition, the examiners while purchasing a residential property place within specific market condition through interpret of estate agents. Finally, the authors have concluded that the respondents purchase behaviour in family decision significantly influenced by estate agents/brokers and the purchasers were comparing their decision with each other in their family and others. This empirical paper provides into the way in which families engage in search practices, interpret information and internally negotiation of their decision. Furthermore, it argues that the findings were contributing a greater understanding of how housing market performed and made.

Ketterer, R. (2002) made an attempt to understand the electronic, virtual real estate brokerage technology integration system and provided methods for a meaningful guidance to buyers and sellers of estate for their process of transaction property.

The examiner was clearly list out the elements for buyers and sellers were require to focus on property transferring process i.e., listing of the property, scheduling of property showing, negotiating the terms of sale, 
searching of listed properties, evaluation of buyer credit worthiness, providing all documents for closing through the internet technology. The author applied dimension reduction technique through the quantitative methodology. The empirical result explore that the system provides a forum for obtaining complementary services such as financing, title searchers, title insurance and other things. The researcher concluded that the virtual technology provides two sets of user interfaces to accomplish all of the aforementioned functions and one set of interfaces for the sellers and one set for the prospective buyers of real estate.

Eraker, D., Dougherty, A. M., Smith, E. M., \& Eraker, S. (2015) explored under an embodiment of the invention and the real estate property classified web page maintains. The author describe that the web page has an aerial image map of a geographic region that can be navigated by a user. The descriptive methodology technique was adopted and data were collected from the real estate website users. The authors were applied a multivariate analyses. The web site system facilitates online collaboration for real estate transactions. When the user registers, the system creates a user account for real estate information. The result derived from is real estate agents and/or other real estate service providers selected by the user are granted shared access to the user's account by the web site system.

Basanta Kumar ,Neelam Chawla , Brajaraj Mohanty (2017) discussed the essential features, merits, and drawbacks of the recently enacted Indian Real Estate Act, 2016, an economic reform measure pertaining to the real estate sector. The paper analyses the impact of the Act and Union Budget 2016 on the inflow of foreign direct investment in India, and examines its ramifications on the world economy. The methodology used in this study is based on secondary data sources, including consumer forum reports, investigative reports from national agencies, court decisions, government websites, real estate companies, and industry associations. A sample survey on the implications of the Act was conducted using Facebook and personal interaction with various stakeholders. The result the Indian real estate sector was unregulated prior to the passage of the Act, which has several provisions aimed at protecting the interest of consumers by tightening fraudulent practices of promoters/developers. Stakeholders are hopeful, but there is some apprehension. The government's budgetary and fiscal support for infrastructure development has had an impact on FDI inflow.

Harvey C Perkins, David C Thorns, Bronwyn M Newton (2008) examined the moderating responsibility of real estate business in the residential housing market with intra-urban place. The researcher focused on real estate advertising because it is the central mediating technique used by sales consultants to incorporate and extend the market activities of a range of actors whose interests and needs are intertwined in the interpretation and representation of people's houses and homes, and those parts of the city in which they are located. The result explores the process of making and deploying such advertising and the ways real estate sales consultants help continually to reinvigorate the meaning of suburbs and other urban localities.

\section{STATEMENT OF THE PROBLEM}

The growth of Indian real estate industry provides many opportunities to the various individual investors to invest their savings in buildings, lands and construction business. There are many individuals perception about the investment avenues are unpredictable and immeasurable. There is a need for clarity to explore the individual behavior to predict the investment in real estate in India.

\section{OBJECTIVES OF THE STUDY}

1. To study the demographic profile of the respondents

2. To classify the respondents based on their behavior towards real estate purchase variables.

\section{RESEARCH METHODOLOGY}

The study was empirically derived with data from cross sectional survey data. The research design of this study was both quantitative and descriptive in nature, and the selected sample was Chennai respondents those who are interested to invest in real estate sector. The sample for the study was 148 and non-probability convenience sampling technique has been applied to collect the primary data from the interested individuals to invest in real estate sector due to not available of comprehensive population in this study.

This survey is empirical and descriptive in nature. The survey questionnaire started with demographic and ended with variable specific question contains behavior of individuals to invest in real estate sector are measured by using five point Likert scale (1-Strongly Disagree, 5-Strongly Agree).

\section{RESULTS AND DISCUSSION}

The sample size was limited to 148 due to time and cost constraint and application of non-probability convenient sampling to collect the primary data from respondents. After the data has been collected, it was processed using SPSS statistics 23 software package was used for the following analysis frequency, descriptive, test of normality, Cronbach's Alpha, cluster analysis and discriminant analysis have been applied.

Table 1: Demographic Profile

\begin{tabular}{|c|c|c|}
\hline & Frequency & Percentage \\
\hline Age (In Years) & & \\
\hline $18-25$ Years & 39 & 27.5 \\
\hline $26-35$ Years & 50 & 35.2 \\
\hline $36-45$ Years & 31 & 21.8 \\
\hline Above 46 Years & 22 & 15.5 \\
\hline Gender & & \\
\hline Male & 70 & 49.3 \\
\hline
\end{tabular}

\begin{tabular}{|c|c|c|}
\hline Female & 72 & 50.7 \\
\hline Educational Qualification & & \\
\hline Below HSC & 9 & 6.3 \\
\hline UG & 59 & 41.5 \\
\hline PG & 50 & 35.2 \\
\hline Professional \& Others & 24 & 16.9 \\
\hline Occupational Status & & \\
\hline Self Employed & 29 & 20.4 \\
\hline
\end{tabular}




\begin{tabular}{|c|c|c|}
\hline Salaried & 73 & 51.4 \\
\hline House Wife & 11 & 7.7 \\
\hline Others & 29 & 20.4 \\
\hline Monthly Income (In Rs.) & & \\
\hline Below Rs.10,000 & 21 & 14.8 \\
\hline Rs.10,000 - Rs.20,000 & 79 & 55.6 \\
\hline Rs.20,000 - Rs.40,000 & 24 & 16.9 \\
\hline Above Rs.40,000 & 18 & 12.7 \\
\hline Area of Living & & \\
\hline Urban & 111 & 78.2 \\
\hline Semi-Urban & 31 & 21.8 \\
\hline Nature of Family & & \\
\hline Nuclear Family & 83 & 58.5 \\
\hline Joint Family & 59 & 41.5 \\
\hline Marital Status & & \\
\hline Married & 88 & 62 \\
\hline Unmarried & 54 & 38 \\
\hline \multicolumn{2}{|l}{}
\end{tabular}

Table 1 indicates that maximum number of respondents is aged between 26 years and 35 years (35.2\%) and undergraduates $(41.5 \%)$. Majority of the respondents are females $(50.7 \%)$, salaried employees $(51.4 \%)$ and earning monthly income between Rs.10,000 and Rs. 20,000. Majority of the respondents are hailing from urban areas $(78.2 \%)$ and nuclear families (58.5\%).

Table 2: Mean Based Ranking for Reasons to Purchasing Property

\begin{tabular}{|l|c|c|}
\hline Reasons to Purchasing Property & Mean (SD) & Rank \\
\hline Investment & $3.98(1.652)$ & III \\
\hline Self - Living & $4.15(1.482)$ & I \\
\hline Marriage Purpose & $4.03(1.484)$ & II \\
\hline Improving Living Standards & $3.44(1.504)$ & IV \\
\hline $\begin{array}{l}\text { Providing Living Space for } \\
\text { Parents }\end{array}$ & $3.05(1.731)$ & V \\
\hline Convenience to Work Place & $2.40(1.725)$ & VI \\
\hline
\end{tabular}

Table 2 indicates that respondents gave preference to Self-Living (Mean $=4.15$ ) for the reasons to purchasing property followed by Marriage Purpose (Mean $=4.03$ ), Investment $($ Mean $=3.98)$, Improving Living Standards $($ Mean $=3.44)$, Providing Living Space for Parents $($ Mean = $3.05)$ and Convenience to work place $($ Mean $=2.40)$ in their importance to purchase the real estate property in their day-to-day life.

Table 3: Descriptive Statistics\& Normality Test

\begin{tabular}{|c|c|c|c|c|c|c|c|c|}
\hline & & & Skewness & Kurtosis & \multicolumn{2}{|c|}{ Tests of Normality } & Reliability \\
\cline { 5 - 9 } Variables & $\begin{array}{c}\text { No. of } \\
\text { Items }\end{array}$ & Mean & $\begin{array}{c}\text { Std. } \\
\text { Deviation }\end{array}$ & $\begin{array}{c}\text { Statistic } \\
\text { Std. Error }= \\
0.199\end{array}$ & $\begin{array}{c}\text { Statistic } \\
\text { Std. Error } \\
=0.247\end{array}$ & $\begin{array}{c}\text { Kolmogorov-Smirnova } \\
\text { (Sig-Value) }\end{array}$ & $\begin{array}{c}\text { Shapiro-Wilk } \\
\text { (Sig-Value) }\end{array}$ & $\begin{array}{c}\text { (Cronbach's } \\
\text { Alpha Value) }\end{array}$ \\
\hline $\begin{array}{c}\text { Economic } \\
\text { Consideration }\end{array}$ & 7 & 2.947 & 0.487 & -0.745 & 0.878 & $0.158(0.000)$ & $.949(0.000)$ & 0.618 \\
\hline $\begin{array}{c}\text { Livelihood } \\
\text { Consideration }\end{array}$ & 7 & 3.362 & 0.492 & -0.134 & 1.379 & $0.091(0.004)$ & $.975(0.009)$ & 0.677 \\
\hline Growth Consideration & 8 & 3.409 & 0.435 & -0.662 & 2.633 & $0.087(0.008)$ & $.959(0.000)$ & 0.656 \\
\hline
\end{tabular}

Table 3 proves that the data collected have normal distribution and test of normality with the help of Kolmogorov- Simrnova Test (p-value $=<0.001)$ and Shapiro-Wilk Test $(\mathrm{p}$-value $=<0.001)$ statistics. The

descriptive statistics indicates that higher mean values and lower standard deviation values to have robust distribution in nature. Table 3 shows that data is normal and fit for multivariate analysis.

Table 4: Cluster Groups of the Respondents based on the Real Estate Purchase Consideration Factors

\begin{tabular}{|c|c|c|c|c|c|c|c|c|c|}
\hline \multirow{2}{*}{ Variables } & \multirow{2}{*}{$\begin{array}{c}\text { Discriminant } \\
\text { Coefficient }\end{array}$} & \multirow{2}{*}{$\begin{array}{l}\text { Discriminant } \\
\text { Loadings }\end{array}$} & \multirow{2}{*}{$\begin{array}{c}\begin{array}{c}\text { Ordinary } \\
\text { Investors }\end{array} \\
\text { Mean } \\
\text { (SD) }\end{array}$} & \multirow{2}{*}{$\begin{array}{c}\text { Return } \\
\text { Seekers } \\
\text { Mean } \\
\text { (SD) }\end{array}$} & \multicolumn{3}{|c|}{$\begin{array}{c}\text { Tests of Equality of Group } \\
\text { Means }\end{array}$} & \multicolumn{2}{|c|}{ t-test } \\
\hline & & & & & $\begin{array}{c}\text { Wilks' } \\
\text { Lambda }\end{array}$ & $\begin{array}{c}\text { F-Value } \\
(\mathrm{df}=\mathbf{1 , 1 4 6 )})\end{array}$ & Sig. & t-value & P-Value \\
\hline $\begin{array}{l}\text { Economic } \\
\text { Consideration }\end{array}$ & 0.628 & 0.575 & $\begin{array}{l}2.500 \\
(0.494)\end{array}$ & $\begin{array}{c}3.113 \\
(0.366) \\
\end{array}$ & 0.685 & 66.986 & 0.000 & -8.184 & 0.000 \\
\hline $\begin{array}{l}\text { Livelihood } \\
\text { Consideration }\end{array}$ & 0.614 & 0.645 & $\begin{array}{c}2.875 \\
(0.403)\end{array}$ & $\begin{array}{c}3.543 \\
(0.389)\end{array}$ & 0.634 & 84.268 & 0.000 & -9.180 & 0.000 \\
\hline \begin{tabular}{|l|} 
Growth \\
Consideration \\
\end{tabular} & 0.377 & 0.645 & $\begin{array}{c}2.973 \\
(0.422)\end{array}$ & $\begin{array}{l}3.570 \\
(0.321)\end{array}$ & 0.634 & 84.268 & 0.000 & -9.178 & 0.000 \\
\hline
\end{tabular}

(Wilks Lamba = 0.419; Chi-square $=125.777, \mathrm{df}=3$, Sig. $=0.000$ )

Eigen Value $=1.388$; Canonical Correlation $=0.762$

$\mathrm{t}$-value =-14.140; P-Value=0.000@ 5\% level of Significant

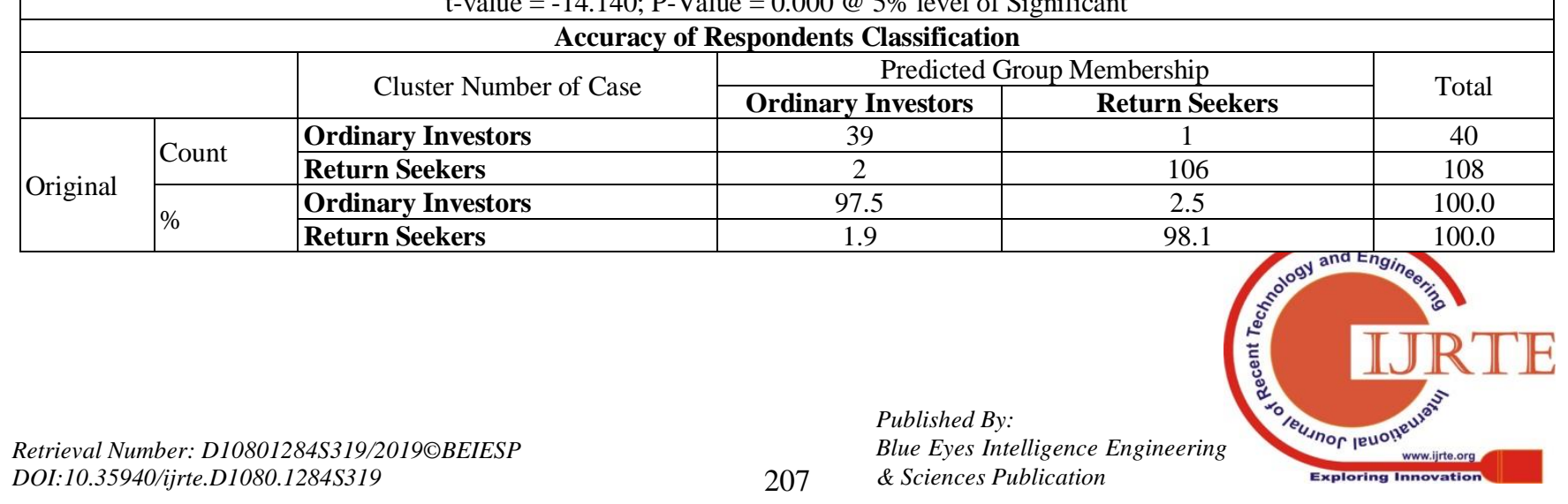


Table 4 indicates that two dominant clusters have been formed significantly differentiated by three real estate purchase consideration factors namely, Economic Consideration Factor, Livelihood Consideration Factor and Growth Consideration Factor. The first cluster formed with 40 respondents and labeled as "Ordinary Investors". The dominant second cluster formed with 108 respondents and labeled as "Returns Seekers". The discriminant function with the eigen value of 1.388, Wilk's Lamda value of 0.419 , chi-square value of 125.777 with degrees of freedom of 3 with P-Value of $<0.001$ proves that cluster classification is significant differentiation of all the real estate purchase consideration factors. In addition, the discriminant analysis result proves that 98.0 percentage of such classification is correct. The results of t-values of three real estate purchase consideration factors are significantly differs with respect to two cluster groups and the mean differences clearly shows that ordinary investors have higher purchase consideration as compared to return investors.

\section{IMPLICATION AND CONCLUSION}

This present study brings out the three important factors that determine the purchase consideration of real estate such as, Economic Consideration Factor, Livelihood Consideration Factor and Growth Consideration Factor are the major determinants of investment decision of ordinary investors as well as return seekers. This study explicit that two types of purchasers are in the realm of real estate industry namely, individual investor and return seekers significantly differentiated with three purchase consideration factors. The real estate purchaser should give focus to livelihood consideration along with economic and growth considerations. Those real estate places which yield more economic considerations within the stipulated time should be given preference among the individual investors and return seekers to have better source of investment. The real estate industry provides higher earnings to the buyers across the country to have better investment decisions and economic growth. Thus, leads to higher industrial growth, enhancement in socio economic conditions, strengthening the financial system, increase in financial leverages and lending among the individuals through different types of financial institutions in India.

\section{REFERENCES}

1. Chawla, N., \& Mohanty, B. (2018). Reform in the Indian real estate sector: an analysis. International Journal of Law and Management, 60(1), 55-68.

2. Eraker, D., Dougherty, A. M., Smith, E. M., \& Eraker, S. (2015). U.S. Patent No. 9,213,461. Washington, DC: U.S. Patent and Trademark Office.

3. Eraker, D., Dougherty, A. M., Smith, E. M., \& Eraker, S. (2015). U.S Patent No. 9,105,061. Washington, DC: U.S. Patent and Trademark Office.

4. IBEF Report (March 2019). Retrieved from online: https://www.ibef.org/download/real-estate-mar-2019.pdf

5. India, PWC Report (2014). Future of India - The Winning Leap. Retrieved from online: https://www.pwc.in/assets/pdfs/future-of-india/future-of-india-the-winn ing-leap.pdf

6. Ketterer, R. (2002). U.S. Patent Application No. 09/901,795.
7. Levy, D., Murphy, L., \& Lee, C. K.-C. (2008). Influences and Emotions: Exploring Family Decision-making Processes when Buying a House. Housing Studies, 23(2), 271-289. doi: 10.1080/02673030801893164

8. Perkins, H. C., Thorns, D. C., \& Newton, B. M. (2008). Real estate advertising and intraurban place meaning: real estate sales consultants at work. Environment and Planning A, 40(9), 2061-2079.

\section{AUTHORS PROFILE}

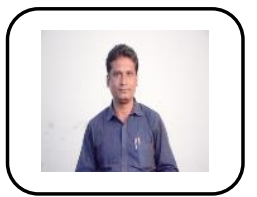

Dr. C. P. Senthilkumar is currently serving as an Assistant Professor in $\mathrm{P} G$ and Research Department of Commerce, Guru Nanak College (Autonomous), Chennai. He is recognized research supervisor guiding doctoral research students leading to the $\mathrm{PhD}$ degrees. He is having more than 20 Years of teaching and research experience in the field of commerce at Post Graduate level. He received Doctoral Degree from Department of Commerce, Annamalai University in the field of finance. He organized various national and international conferences, colloquium and workshops for the betterment of academic fraternity. He participated and presented numerous research papers in various national and international conferences. He contributed many academic writings and contribution to the leading journals in the field of commerce and management. He is panel member and subject expert for the various city colleges in Chennai.

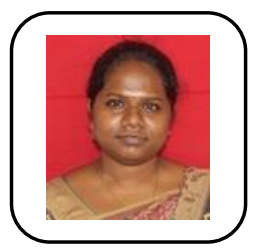

M. Karthiga Priya is a passionate academician currently serving as an Assistant Professor in Department of Corporate Secrateryship of Chevalier T Thomas Elizabeth College for Women, Chennai. She is perusing her doctoral research from Center for Research in Commerce, Guru Nanak College (Autonomous), Chennai in the field of marketing and consumer behavior.

She was qualified TNSET in the year 2016 from Mother Theresa Women's University, Kodaikanal, Tamil Nadu. She received her Post Graduation and Pre Doctoral Degree from Department of Commerce, University of Madras. She has teaching experience of six years at under graduate level and specalised in accounting and finance. She is actively participating and presenting various research papers in the many national and international conferences. 